\title{
Morphological Priming in Spanish Verb Forms: An ERP Repetition Priming Study
}

\author{
Antoni Rodriguez-Fornells ${ }^{1}$, Thomas F. Münte ${ }^{1}$, and Harald Clahsen ${ }^{2}$
}

\begin{abstract}
The ERP repetition priming paradigm has been shown to be sensitive to the processing differences between regular and irregular verb forms in English and German. The purpose of the present study is to extend this research to a language with a different inflectional system, Spanish. The design (delayed visual repetition priming) was adopted from our previous study on English, and the specific linguistic phenomena we examined are priming relations between different kinds of stem (or root) forms. There were two experimental conditions: In the first condition, the prime and the target shared the same stem form, e.g., "ando-andar" [I walk-to walk], whereas in the second condition, the prime contained a marked (alternated) stem, e.g., "duermodormir" [I sleep-to sleep]. A reduced N400 was found for
\end{abstract}

\section{INTRODUCTION}

Inflected words in English and other Germanic languages fall into two clusters with different linguistic properties. The first one is represented by regularly inflected words that take a stem and combine it with an affix, yielding concatenated forms such as "walk + ed." The second kind is represented by irregularly inflected words such as "went" or "was," which cannot be decomposed into stems and affixes. Hence, in linguistic terms, regular and irregular inflection are based on two different kinds of representations. Regular forms such as "walked" are characterized as rule-based, that is, derived from the stem by applying an "-ed" affixation rule. Irregular forms, on the other hand, are thought to be represented in separate lexical entries. It has been argued that the linguistic properties of regularly and irregularly inflected words correspond to the way they are processed, in that concatenated word forms are segmented or parsed into their constituent morphemes, while irregular forms are stored as whole forms in memory (Clahsen, 1999; Marslen-Wilson \& Tyler, 1998; Pinker, 1997). An alternative theoretical viewpoint is represented by connectionist single-mechanism models of inflection (see, e.g., Elman,

\footnotetext{
${ }^{1}$ Otto von Guericke University, Magdeburg, Germany, ${ }^{2}$ University of Essex, Colchester, UK
}

unmarked (nonalternated) stems in the primed condition, whereas marked stems showed no such effect. Moreover, control conditions demonstrated that the surface form properties (i.e., the different degree of phonetic and orthographic overlap between primes and targets) do not explain the observed priming difference. The ERP priming effect for verb forms with unmarked stems in Spanish is parallel to that found for regularly inflected verb forms in English and German. We argue that effective priming is possible because prime target pairs such as "ando-andar" access the same lexical entry for their stems. By contrast, verb forms with alternated stems (e.g., "duermo") constitute separate lexical entries, and are therefore less powerful primes for their corresponding base forms.

Bates, Johnson, et al., 1996, for a review) according to which the morphological structure of words plays no direct role in the way inflected words are produced or perceived. Instead, all inflected words are assumed to be stored as full forms in memory, and all kinds of morphological patterns including those that can be decomposed into stems, roots, and affixes are claimed to be derivable from associative networks.

Recently, several neuropsychological (Cappa \& Ullman, 1998; Marslen-Wilson \& Tyler, 1997) and brain imaging studies (Münte, Say, Clahsen, Schiltz, \& Kutas, 1999; Indefrey et al., 1997; Penke et al., 1997; Ullman, Corkin, Coppola, et al., 1997; Weyerts, Penke, Dohrn, Clahsen, \& Münte, 1997; Jaeger et al., 1996; Weyerts, Münte, Smid, \& Heinze, 1996) have produced data that have been interpreted to support such a "dual-mechanism model." While double dissociations are a standard means of determining independent processes in neuropsychology, Joanisse and Seidenberg (1999), proponents of a connectionist single-mechanism account, have argued on the basis of a modeling study that dissociations might be explained by differential input of semantic and phonological information to the computation of complex word forms in a single-mechanism system. Likewise, Seidenberg and Hoeffner (1998) have criticized one of the early neuroimaging studies (Jaeger et al., 1996) as not being a crucial test for single- 
mechanism models. On the other hand, based on the fact that brain imaging studies have revealed multiple active brain regions during the processing of regular and irregular items, two of us have argued that the singleversus dual-mechanism debate may fall short of explaining the complex pattern of differences of regular and irregular processing with respect to the brain (Münte, Rodriguez-Fornells, \& Kutas, 1999). Thus, the debate on the differences between the processing of regular and irregular words is far from settled and more data are needed.

Most studies of inflectional phenomena have been conducted in English and German. In other languages, however, particularly in those with richer inflectional systems, the distinction between rule- and memorybased inflectional processes is less straightforward. In Spanish, for example, verbs fall into classes or conjugations (see below for details). The question this poses for morphological processing models is how to deal with a system where on the one hand a regular, productive morphological class (i.e., first conjugation) contrasts with nonproductive or semiproductive classes (second and third conjugation) within which regular and irregular inflections are distinguished. To assess the crosslinguistic validity of single- versus dual-mechanism models of language, a number of recent studies have extended the research on the mental representation and processing of morphologically complex words to the Romance languages (Rodriguez-Fornells, Clahsen, Lleó, Zaake, \& Münte, 2001; Say \& Clahsen, 2002; Gross, Say, Kleingers, Clahsen, \& Münte, 1998; Orsolini \& Marslen-Wilson, 1997; Elman et al., 1996). The theoretical interpretation of the data on Romance inflection, however, has remained controversial.

Against this background, the present study examines inflected words in Spanish using event-related brain potentials (ERPs), in particular different kinds of stem forms. Compare, for example, first-segment presenttense forms such as "and-o" from the verb "and-ar" [to walk] with "duerm-o" from the verb "dorm-ir" [to sleep]. Note, that both "and-O" and "duerm-o" share the same inflectional ending "-o," which encodes the first-segment present tense, and that this ending is decomposable from the stem. The difference between the two forms is that "and-o" has an unmarked stem/ root form that is identical to that of the infinitive, whereas "duerm-o" employs a marked (alternated) stem/root that is different from that of the infinitive. This contrasts with inflected verb forms in English where regulars (e.g., "walk-ed") have a decomposable ending but no stem changes, and irregulars (e.g., "came") have stem changes but no segmentable ending. Our previous research on Catalan and Italian (Rodriguez-Fornells et al., 2001; Say \& Clahsen, 2002; Gross et al., 1998) suggests that the regular (default)/irregular (marked) distinction posited in the dual-mechanism model applies to the different kinds of stem/root forms that are found in these languages. The present study extends this research to Spanish.

One way of experimentally studying morphological relationships between different word forms utilizes the priming paradigm. A priming experiment examines the extent to which a prior presentation of a morphologically related word form (e.g., "walked") facilitates the recognition of a corresponding target form (e.g., "walk"). In behavioral experiments on English and German, regular past-tense forms have been found to more effectively prime their corresponding base forms ("walked" $\rightarrow$ "walk") than irregular ones ("came" $\rightarrow$ "come") (Stanners, Neiser, Hernon, \& Hall, 1979; see also Sonnenstuhl, Eisenbeiss, \& Clahsen, 1999; MarslenWilson \& Tyler, 1997). Assuming that part of the repetition priming effect reflects facilitated access to its lexical entry upon second exposure, these priming differences seem congruent with ideas postulated by the dual-mechanism model: Regularly inflected word forms are processed via their constituent morphemes and thereby directly access the same lexical entry as the target forms; hence, they are more effective primes for their corresponding base forms than irregular ones that access their own lexical entries and can therefore prime their corresponding base forms only indirectly.

ERPs have also been used to study brain activity in the repetition priming task. A widespread positivity, sometimes called the old-new effect, has been reported for repeated items with an onset latency between 200 and $300 \mathrm{msec}$ and a duration of several hundred milliseconds (see Rugg, 1995, for a review; also Doyle, Rugg, \& Wells, 1996; Karayanidis, Andrews, Ward, \& McConaghy, 1991; Bentin \& Peled, 1990; Nagy \& Rugg, 1989; Rugg \& Nagy, 1987). This repetition priming effect is preserved when first and second presentations of a word are separated by a number of unrelated items (Karayanidis et al., 1991; Nagy \& Rugg, 1989) and is also seen for immediate repetitions of orthographically legal nonwords (e.g., "nopru") (Rugg \& Nagy, 1987). The effect for legal nonwords has not been found with inter-items lags of one or more words (Bentin \& Peled, 1990). In addition, no effect has been obtained using orthographically illegal nonwords (e.g., "grlkid”) (Rugg \& Nagy, 1987). The old-new effect comprises the modulation of at least two different ERP components: (a) the N400 component related to semantic processing (Rugg, 1990) and (b) a late positive component related to the retrieval of information from memory (Van Petten, Kutas, Kluender, Mitchiner, et al., 1991; Rugg, 1990). A similar effect was found using a formal priming situation, in which primes and targets shared orthographic similarities without sharing a lexical entry (e.g., "scan-scandal") (Doyle et al., 1996).

In a recent ERP priming study on the English past tense (Münte, Say, et al., 1999), stem forms ("walk") primed by regularly inflected past-tense forms ("walked") with five to nine intervening items showed 
a reduced $\mathrm{N} 400$ (i.e., a more positive-going ERP waveform between 250 and $400 \mathrm{msec}$ ) relative to unprimed stems. No such effect was observed either for irregular verbs or for other control conditions that exhibited the same degree of orthographic and phonological overlap to their targets as regularly inflected verbs ("card" $\rightarrow$ "car"). This ERP effect was interpreted as being consistent with the view that regular past-tense forms are morphologically decomposed, thereby making the unmarked stem (e.g., "walk") available for priming. Reduced priming for irregular prime target pairs, on the other hand, was taken to indicate that irregular pasttense forms are not morphologically decomposed, but rather access separate lexical entries. Similar results were obtained in an ERP priming study of participle forms in German (Weyerts et al., 1996).

The specific question we will examine in the present study is whether the priming differences that were found for regular and irregular word forms in English and German are also found for the different kinds of stem forms (unmarked vs. marked) that are common in Spanish (as well as in other languages). In Spanish and other Romance languages, inflections are organized into three morphological classes, called "conjugations." Each conjugation has its characteristic thematic vowel, for example, first conjugation verbs have the "-a-" in Spanish ("estudi- $\boldsymbol{a}$-r" [to study]), second conjugation verbs "-e-" ("com-e-r" [to eat]), and third conjugation "-i-" ("viv- $i$-r" [to live]). The "-ar" group, derived from the Latin first conjugation ("-are") is the largest and most productive one, that is, new words are typically incorporated into the language as first conjugation verbs, for example, English "to stress" becomes Spanish "estres-ar." The order of the various constituents of Spanish verbs is fixed is as follows: root + thematic vowel + inflectional suffixes. There are many Spanish verbs with forms that deviate from this regular pattern of verb formation, most of which are due to changes in the stem or root form. To examine how stem/root changes affect the morphological processing of an inflected word, we have studied first-person singular presenttense forms in Spanish.

The first-person singular of the present tense is constructed by directly attaching an "-o" to the verb root. There is no theme vowel in these forms, and the inflectional ending ("-o") is identical in all three conjugations, e.g., "estudi-o" [I study] (infinitive: "estudiar" [to study]), "tem-o" [I fear] (infinitive: "temer" [to fear], "part-o" [I leave] (infinitive: "partir" [to leave]). Vowel alternations affecting the stem/root of the verb are common in the present tense (Real Academia Española, 1998). Such alternations involve changes between unstressed "e" and stressed "ie," as in "quer'er" [to want]-"qu'iero" [I want] (more rarely between "i" and "ie," "adquir'ir" [to acquire]-"adqu'iero" [I acquire], or between unstressed "o" and stressed "ue," as in "volv'er" [to come back] -"v'uelvo" [I come back], and between "u" and "ue" as in "jug'ar" [to play]"j'uego" [I play]. What is common to these alternations is that they involve a phonological change in which front or back vowels change to diphthongs when stressed ("e"/ "ii" "ie" and "o"/ "u" "ue"). In addition, there is a group of approximately 35 verbs of the third conjugation that have alternations of "e" with "i," for example, "p $i$ do" [I ask for]-"pedir" [to ask for]; these verbs have stem forms that end in single consonants or in the clusters (e.g., "rv," "st," "nd," "nch"; Bybee \& Pardo, 1981). Note also that the inflectional suffixes for the first-singular present tense is "-o," irrespective of whether or not the stem to which "-o" is attached has an alternated vowel. Thus, the contrast between forms such as "ando-andar" and "duermo-dormir" in Spanish represents a way to study how stem/root changes affect morphological processing independently of the form of the inflectional ending.

Many linguists have argued that these alternations can be derived from general phonological rules, such as diphthongization, because they can be predicted, for example, on the basis of stress, and because alternations are common throughout the vocabulary (see, e.g., Harris, 1969). On the other hand, the stem/root alternations we mentioned could be thought of as "lexically" determined in the sense that the verbs with alternated stems form an arbitrary class. There are many verbs that have front or back vowels that do not undergo diphthongization, for example, "notar-noto" [to note-I note], and there are many third conjugation verbs with a front vowel in the infinitive that (unlike "pedir-pido" [to ask for-I ask for]) are not subject to a simple "e $\sim$ i" change, for example, "mentir-miento" [to lie-I lie]. One way to further shed light on this distinction is by using nonce words, that is, word-like stimuli that respect the orthographical and phonological principles of the language under investigation (e.g., English: "brapped"). For example, a nonce probe task administered to Spanish-speaking adults (Bybee \& Pardo, 1981) revealed that "subjects are extremely reluctant to introduce an alternation into a nonce verb" (p. 941). As far as diphthong/vowel alternations are concerned, only 36\% of the subjects $(n=22)$ applied the phonological change as expected, indicating that these kinds of alternations have restricted productivity and do not easily extend to new lexical items. As an alternative to deriving these alternations from general phonological rules, we may therefore hypothesize that verbs with alternated stem or root forms have structured lexical entries with an unmarked base form ("dorm-") and a subentry for the altered stem/root form ("duerm-") (see Wunderlich, 1996, on structured lexical entries). On the other hand, verbs such as "hablar" [to speak], which do not show any alternations, have one single lexical entry. On this analysis, we predict that verb forms with alternated stems yield a priming pattern similar to that of irregular past-tense forms in English, while verb forms 
Table 1. Mean Reaction Times $\pm S D$ for Verbs and Nonce Verbs

\begin{tabular}{|c|c|c|c|}
\hline & \multirow[t]{2}{*}{ Prime } & \multicolumn{2}{|c|}{ Targets } \\
\hline & & Unprimed & Primed \\
\hline Verbs with alternated stems ("irregular") & "entiendo": $700 \pm 71$ & “querer”: $672 \pm 82$ & “entender”: $650 \pm 78$ \\
\hline Verbs with nonalternated stems ("regular") & "ando": $663 \pm 78$ & "lavar": $623 \pm 68$ & "andar": $596 \pm 63$ \\
\hline Nonce verbs with alternated stems ("irregular") & "miero": $756 \pm 99$ & "romar": $749 \pm 119$ & "merer": $741 \pm 105$ \\
\hline Nonce verbs with nonalternated stems ("regular") & "poto": $743 \pm 109$ & "vafar": $764 \pm 109$ & "potar": $765 \pm 104$ \\
\hline
\end{tabular}

with nonalternated stems should be associated with a priming effect similar to that of regular past-tense forms in English. This is because in both languages, the marked forms (e.g., "duerm-" and "came") access their own entries and should therefore prime their corresponding infinitive forms less effectively than the nonalternated forms, which access the same stem form as their targets ("and-andar" [walk-walked]).

\section{RESULTS}

\section{Performance Data}

In Table 1, mean reaction times (RT) and standard deviation $(S D)$ are shown for each condition. RTs for nonce verbs were slower than those for existing verbs, $F(1,13)=43.2, p<.001$. The generally faster RTs for "regular" (nonalternated) verb forms led to a main effect of regularity, $F(1,13)=9.1, p<.01$. As this regularity effect was restricted to existing verbs, a Word $\times$ Regularity interaction was obtained, $F(1,13)=54, p<$ .001. A general effect of priming was found: Primed infinitives led to faster RTs than unprimed infinitive forms, $F(1,13)=13.5, p<.01$. However, a priming effect was only observed for existing words and not for nonce verbs [Word $\times$ Priming, $F(1,13)=5.4, p<.05$ ] The priming effect for existing verbs was larger for verbs with nonalternated stem forms than for those with alternated stems, but the difference between these two conditions was not statistically significant, $F(1,13)<1$. ${ }^{1}$

The percentage of errors was similar for verbs $(9.5 \%)$ and nonce verbs $(10.4 \%), F(1,13)<1$. While verb forms with vowel alternations produced a larger percentage of errors than nonalternated forms $[12.2 \%$ vs. $7.8 \%$, respectively, $F(1,13)=58, p<.001]$, this effect was restricted to existing words, as can be seen from a significant Word $\times$ Regularity interaction, $F(1,13)=38, p<.001$. The different priming conditions, on the other hand, did not affect the percentage of errors, $F(1,13)=1.5$.

\section{ERPs}

The grand average ERPs for each experimental condition (primed vs. unprimed in existing verbs and in nonce verbs) are depicted in Figure 2A. These are characterized by a small negativity (peaking around 80-100 msec) that resolved in a widespread P200 component. Up to this positive peak, the morphology of the waveforms is virtually identical for primed and unprimed targets in each condition. From 200 msec onwards, an increased positivity can be seen at central and posterior sites for the primed "regular" verbs only (see Figure 3). This is reflected in an interaction effect between regularity and priming in the 200-400-msec time window, $F(1,13)=$ $7.06, p<.05$. None of the main effects were significant for this interval [priming: $F(1,13)=1.23$; regularity: $F(1,13)<1]$. In the next time window (400-600 msec), the interaction of priming and regularity disappears, $F(1,13)=1.51$, with the main effects again being nonsignificant [priming: $F(1,13)=2.41, p>.144$; regularity: $F(1,13)=1.47]$.

The analyses of variance (ANOVAs) performed on the nonce verbs showed no effect of either regularity or priming and no interaction between priming and regularity [in both time windows, $F(1,13)<1$ ] . A summary of

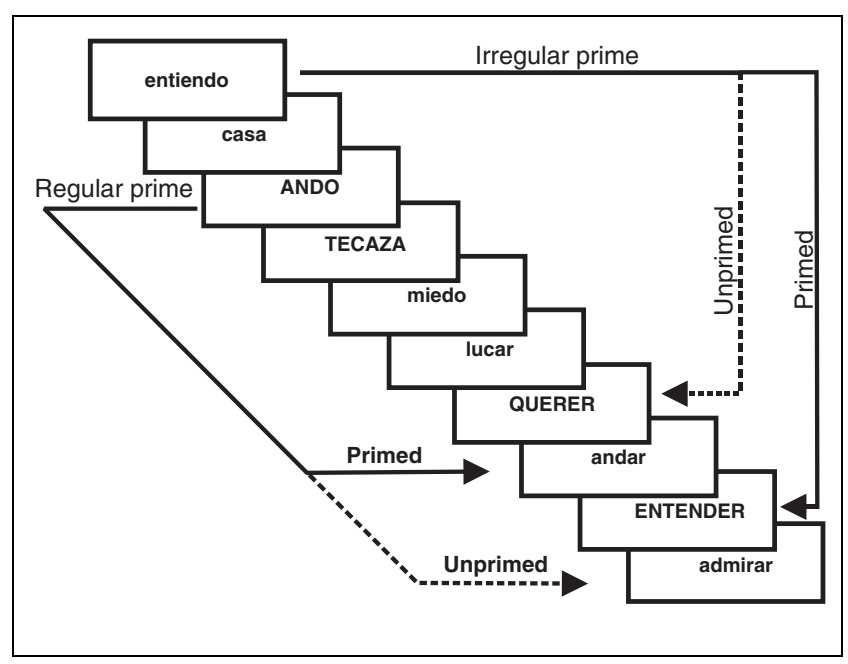

Figure 1. Schematic illustration of the trial structure in the lexical decision task, where pairs of verb forms with "regular" (nonalternated) and "irregular" (alternated) stem forms in prime-primed and primeunprimed conditions were embedded in word/nonce word lists. Primed and unprimed presentations occurred after a variable number of items (range of five to nine items) from the point at which the prime word appeared and were always in a different letter format than the prime word. 
Figure 2. (A) Grand average ERPs $(n=14)$ elicited by primed and unprimed words. Midline frontal, central, and parietal sites are depicted for each "regular" (nonalternated) and "irregular" (alternated) form of existing and nonce verbs. (B) Topographical map for "regular" forms of the normalized distribution of the difference waveform (primedunprimed target forms) using isovoltage mapping with spherical spline interpolation (top view). Depicted is the mean amplitude in the 200-400-msec time windows. (C) Mean differences in amplitude (primedunprimed target forms) between 200-400- and 400-600msec time windows averaged for all central posterior electrodes. The differences are depicted separately for "regular" (nonalternated) and "irregular" (alternated) verb forms (V) and nonce verb forms $(\mathrm{N})$.

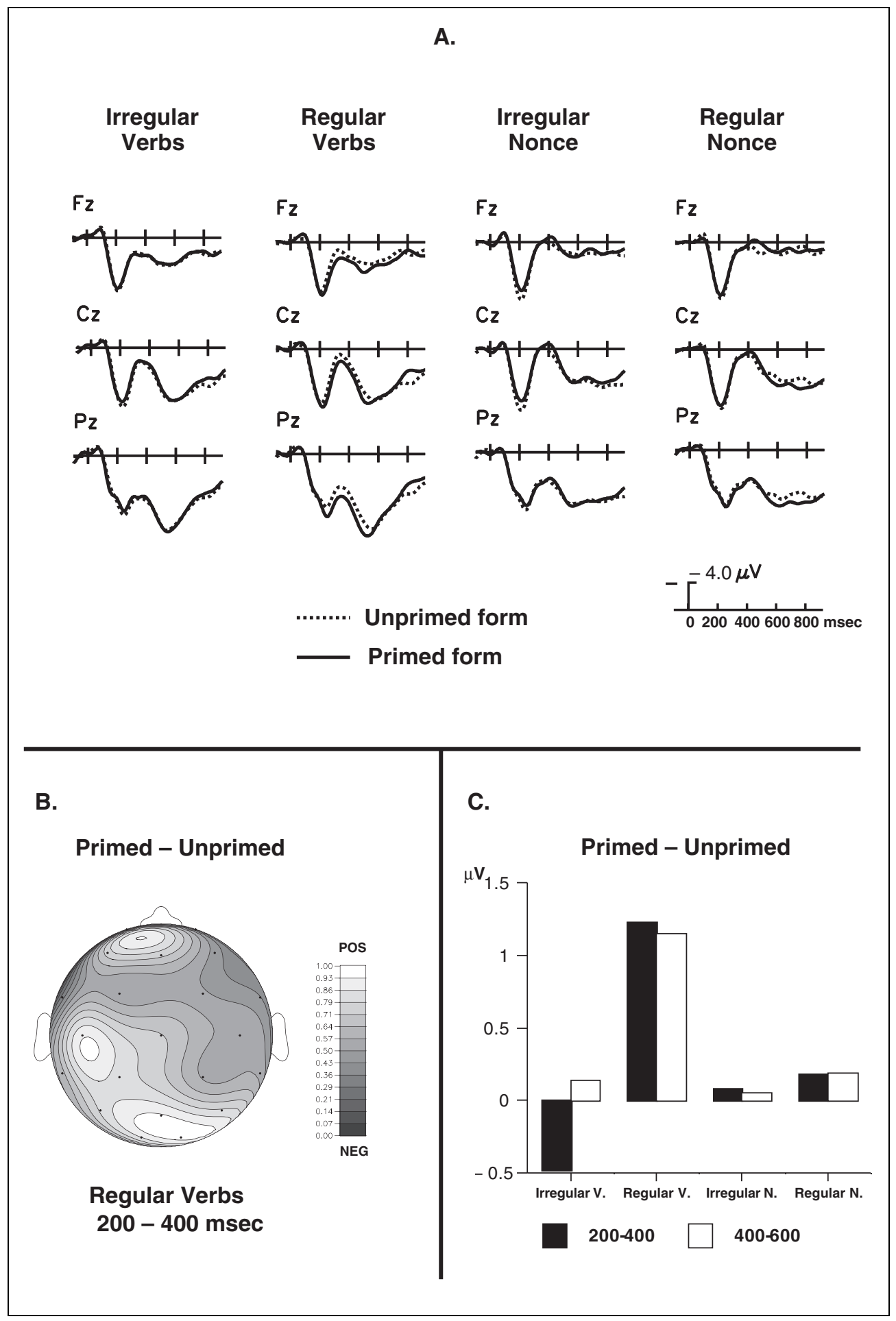

the priming effects (primed-unprimed forms) in both time windows is depicted in Figure $2 \mathrm{C}$ showing the mean amplitude of the electrodes that were also used for the ANOVA.

The topographic distribution of the priming effect for the "regular" (nonalternated) forms of existing verbs is depicted in Figure 2B. A clear posterior maximum emerges, which-in keeping with the literature on the N400_-shows a slight right-hemispheric preponderance.
A second maximum is seen over left central cortex. This distribution was reflected in a triple order interaction of Regularity $\times$ Hemisphere $\times$ Electrode in the 200-400msec time window [existing verbs, $F(4,52)=5.5, p<.01$ ]

\section{DISCUSSION}

The most important finding of the present study is the ERP priming effect that was found for inflected verb 
Figure 3. (A) Grand average ERPs for the primed and unprimed words in the "regular" (nonalternated) verb condition. (B) Irregular verb condition. Recordings are shown from the 10/20 scalp locations.

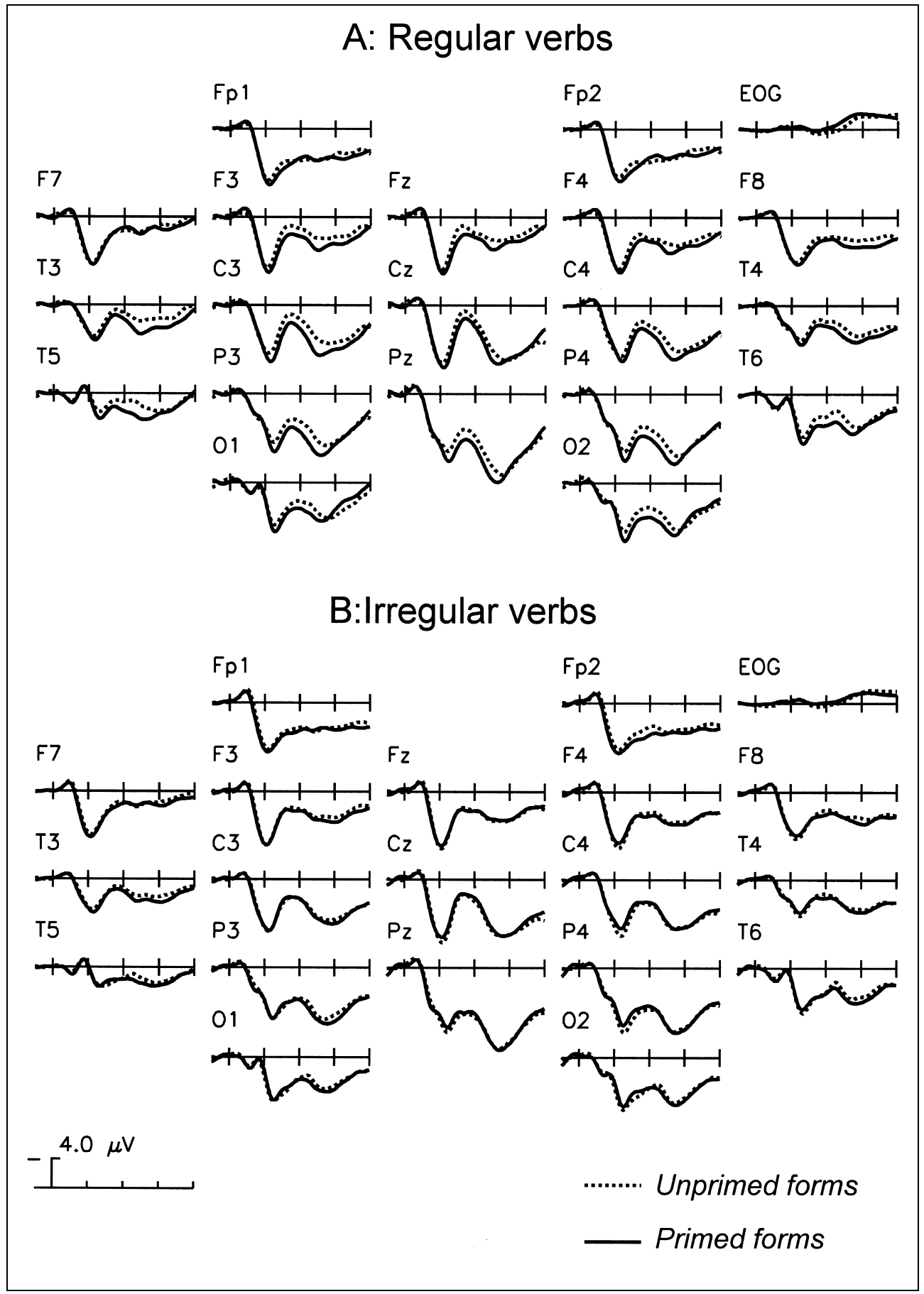

forms with nonalternated stems ("ando-andar"), but not for inflected forms with alternated stems ("duermo-dormir"). In terms of its latency and distribution, the priming effect is likely to represent a modulation of the N400 component; it begins at about $250 \mathrm{msec}$, ends at about $450 \mathrm{msec}$, and has a maximum over the right posterior scalp. The effect is reminiscent of the findings of two previous ERP priming studies on regular and irregular inflection in English and German (Münte, Say, et al., 1999; Weyerts et al., 1996) in which a reduced
N400 was found for primed regular verbs ("walkedwalk"), but not for primed irregulars ("came-come"). ${ }^{2}$ We attribute the observed ERP priming differences in these three languages to a "morphological" difference between the word forms involved. Irregular verb forms in English and German (e.g., "came," "gesungen", [sang]) and alternated stems in Spanish (e.g., "duerm-") form lexical entries separate from (or rather subentries to) their corresponding base forms ("come," "sing-," and "dorm-") and can therefore access these only 
indirectly. Regular verb forms in English and German ("walked," "getanzt" [danced]) and nonalternated stems in Spanish ("ando"), on the other hand, can directly access their unmarked base forms ("walk-," "tanz-," "and-") as a result of morphological decomposition ("walk + ed," "ge-tanz + t," and "+ o"). The observed ERP priming patterns correspond to these morphological distinctions.

In addition to ERPs, two kinds of behavioral data were obtained in the present study, error scores and RTs from a delayed visual word/nonword discrimination task. In terms of the error scores, there was a clear difference between alternated and nonalternated forms, with the former producing significantly more incorrect word/nonword decisions than the latter. This finding is in line with the difference found in the ERP data. The RT data, on the other hand, showed small priming effects for both word classes $(22 \mathrm{msec}$ in the irregulars and $27 \mathrm{msec}$ in the regulars). While virtually every morphological priming experiment has revealed an RT facilitation for primed regular words (e.g., Marslen-Wilson, Hare, \& Older, 1993; Napps, 1989; Fowler, Napps, \& Feldman, 1985, Kempley \& Morton, 1982) results for irregular words have been largely inconsistent. Stanners et al. (1979), in one of the earliest studies, have seen reduced facilitation for irregular compared to regular words, while Kempley and Morton (1982) found no priming at all. Finally, Fowler et al. (1985) found a full priming effect of irregulars. In a very refined study, Marslen-Wilson, Hare, and Older (1993) investigated two subclasses of irregular pasttense forms: (1) verbs such as "burnt-burn" and "felt-feel" with vowel changes and "-t" as the final consonant and (2) verbs such as "sang-sing" and "gave-give" with vowel changes only. They compared these irregular types with regular past-tense forms in a cross-modal priming task. Only the regular past-tense forms produced full priming. The past-tense forms of the "burn-burnt" class yielded no priming, whereas those of the "give-gave" class actually led to an interference effect, with response times being significantly slower than following unrelated primes. Thus, RT priming effects to irregular words have been notoriously variable and difficult to replicate.

In any case, a dissociation between RT data and the N400 effect as in the current study has been previously reported in other paradigms (e.g., Chwilla, 1996; Brown \& Hagoort, 1993; Holcomb, 1993; Kounious \& Holcomb, 1992). These dissociations underscore that $\mathrm{N} 400$ and RT are not necessarily sensitive to the same cognitive processes. RT reflects the final outcome of the entire information processing sequence under study, while the N400 component indexes some intermediate stage of analysis. As regular and irregular words were dissociated by the N400, we will focus on this finding in then next few paragraphs. The exact nature of the process underlying the N400 is still under debate. While some findings suggest it to reflect controlled processes such as (postlexical) semantic meaning integration (Chwilla, 1996; Holcomb, 1993), other research indicates that the N400 might also be sensitive to unconscious, automatic meaning access (Vogel, Luck, \& Shapiro, 1998; Luck, Vogel, \& Shapiro, 1996). In a very general sense, Kutas and Federmeier (2000) state that "semantic information accrues ... throughout the processing of a sentence, discourse, or even, a list of words." This information is then used to preactivate perceptual and semantic features of forthcoming items, such that these items are "easier to assimilate and process." This ease of processing is reflected in a reduced N400 amplitude. By this account primed target forms of regular verbs easier to process. The most parsimonious explanation for this is that both forms actually access the same lexical representation and that this representation is preactivated by the prime. The lack of an N400 effect for the irregular verbs on the other hand suggests that the memory trace that was formed by the prime did not activate the representation of the target sufficiently to yield an N400 reduction.

Before this interpretation is accepted, one further point needs to be addressed: The items in the two critical conditions differed not only in terms of their morphological structure, but also with respect to their surface form similarity, namely, the degree of orthographic and phonetic overlap between prime and target stimuli. Inflected verbs with nonalternated stem forms in Spanish are orthographically and phonologically more similar to their base forms than verbs with alternated stems. It must therefore be asked, whether this difference in surface form might be the reason why nonalternated stems are more effective primes for their corresponding base forms than alternated ones. The same argument has been made to account for priming differences between regular and irregular past-tense forms in English (Rueckl, Mikolinskis, Raveh, Miner, et al., 1997). Note, however, that the current experiment (as in its predecessor in English; Münte, Say, et al., 1999), steps were taken to reduce potential effects resulting from direct surface form priming. Primes and targets were presented in different fonts (upper/lower case), and a long inter-item lag was introduced between prime target pairs to minimize effects of perceptual priming such as those reported by Doyle et al. (1996). Moreover, in order to directly assess the potential effects of surface form similarity in the absence of lexical entries, two nonce word conditions were included in our priming experiments with prime target pairs that were matched to the two critical conditions in terms of their degree of formal prime target overlap. We found that while regular/nonalternated prime target pairs of existing verbs elicited an N400 modulation, the nonce word conditions, even those that had the same formal overlap as the critical "regular" condition, did not produce any ERP priming effect. This indicates that the 
ERP effect for regular verbs cannot be attributed to lowlevel surface form priming.

\section{Conclusion}

We found that marked stem forms in Spanish elicit brain potentials similar to those produced by irregular word forms in English and German, whereas unmarked stem forms produce ERP effects parallel to those of regularly inflected words in English and German. In addition to our previous results on Italian and Catalan, the present findings demonstrate the replicability of ERP effects across different languages and the sensitivity of ERPs to the properties of morphologically different word forms. From a linguistic perspective, the observed ERP priming patterns provide experimental support for the view that morphologically conditioned alternations are not governed by general phonological rules, but that marked stems (similarly to irregularly inflected words) access their own mental representations. ${ }^{3}$

\section{METHODS}

Fourteen neurologically healthy native speakers of Spanish (9 women, all right handed, age range 2030) gave informed consent to participate in the present experiment.

Two lists of 110 verbs each were constructed. The first list consisted of verbs such as "andar" that have nonalternated stems in their first-segment present-tense forms, while the second one contained verbs such as "dormir" with alternated stems in the first-segment present tense (see Appendix). In what follows, the first list will be labeled "regular" and the second one "irregular." On the basis of a frequency dictionary (Alameda \& Cuetos, 1995), both lists were matched for the frequency of the infinitives ("irregular": 15.9 per million, regular: 15.3 per million) and the frequency of the present-tense forms ("irregular": 5.0 per million, "regular": 5.17 per million). Both lists were also matched for mean word length ("irregular": 7.07/6.94 letters for infinitive/ present tense; "regular": 7.22/6.23 letters for infinitive/ present tense) and for the number of verbs from each conjugation (first conjugation: 66, second conjugation: 16, third conjugation: 28). The "irregular" list was also checked (using Moliner, 1998; Real Academia Española, 1998; Alameda \& Cuetos, 1995) with respect to the following criteria: (a) the same base verb was not used more than once; (b) present-tense forms that might also be interpreted as nouns were only included if the frequency of the noun was less than 20 per million; (c) verbs with alternated stems that can also be used with nonalternated unmarked stems in colloquial Spanish were not included (e.g., "desolar-desuelo" [to desolate], but also "desolo" [I desolate]); (d) verbs that are not in current usage were also rejected from the list. The resulting list of 110 items comprised 15 forms with the "e" "i" alternation, 53 forms with "e" "ie," 39 forms with "o" "ue," 1 form with "i" "ie," and 2 forms with "ae" "ai." In addition to the "regular" and "irregular" lists, two lists of 110 nonce verbs were constructed, one with nonalternated and one with alternated stem forms. These two lists were created by changing one or two letters of the existing items in the "regular" and the "irregular" lists. The resulting nonce words were checked by a native speaker for plausibility with respect to the phonotactic rules of Spanish and for any phonological overlap to existing words. Finally, there was a group of 150 filler items, 75 existing words, and 75 nonce words.

These stimuli were arranged into lists in which in the primed condition first-person singular present-tense forms preceded corresponding infinitive forms (e.g., "ando/andar," "duermo/dormir") with an inter-item lag of five to nine items. In the unprimed condition, the infinitive forms were preceded by present-tense forms of unrelated words from the same stimulus group, e.g., "amar" [to love] was preceded by an unrelated firstsegment present-tense form with a nonalternated stem, and an infinitive such as "empezar" [to begin] was preceded by an unrelated first-segment present-tense form with an alternated stem, e.g., "confieso" [I confess] (see Figure 1 for illustration). Each stimulus was presented only once in the same form during the experiment. Two different scenarios were created in order to ensure that-across subjects-each verb was shown equally often in the related (primed) and in the unrelated (unprimed) conditions. Each scenario contained 55 prime words from each list ("regular" and "irregular") that were followed by a related target verb in the infinitive ("ando-andar" [I walk-to walk]) as well as an unrelated target verb ("ando-lavar" [I walk-to wash]). Thus each prime was followed both by a related infinitive and by an unrelated infinitive. The order of presentation (first or second) of related and unrelated infinitives was balanced. Thus, each of the averages is based on 55 items.

A lag of five to nine words was used in the present experiment to minimize effects resulting from perceptual overlap between primes and targets (cf. the results of Doyle et al., 1996, on repetition priming). As an additional measure, half of the stimuli appeared in uppercase letters, the other half in lowercase letters in a pseudorandom order, making sure that prime and target words were presented in different letter formats. Each word was presented for $300 \mathrm{msec}$ with a stimulus onset asynchrony varying randomly between 1500 and 2000 msec (rectangular distribution). After each stimulus, a fixation point remained in the center of the screen. Subjects were required to perform a lexical decision task (word/nonword discrimination) for each stimulus. The participants reacted by pressing one of two response buttons (one for words, the other for nonce words). Hand assignments were counterbalanced across subjects. 
The electroencephalogram (EEG) was recorded from the scalp using tin electrodes mounted in an elastic cap (Electro-Cap International) and located at 29 standard scalp locations (Fz, Cz, Pz, Fp1/2, F3/4, Fc1/2, C3/4, Cp1/ 2, P3/4, O1/2, F7/8, FC5/6, T3/4, T5/6, Cp5/6, PO1/2). All scalp electrodes were re-referenced off-line to the average of both mastoids. Vertical eye movements were monitored with an electrode below the right eye (vertical electrooculogram, EOG). All electrode impedances (EEG and EOG) were kept below $5 \mathrm{k} \Omega$. The electrophysiological signals were filtered with a bandpass of 0.01-70 Hz (half-amplitude cutoffs) and digitized at a rate of $250 \mathrm{~Hz}$. Trials in which either base-to-peak EOG amplitude exceeded $50 \mu \mathrm{V}$, or amplifier saturation occurred, or the baseline shift exceeded $200 \mu \mathrm{V} / \mathrm{s}$, were automatically rejected off-line (mean percentage of rejection was 21.5\%). The EEG was averaged separately for each word-class for epochs of $1024 \mathrm{msec}$ including a 100-msec prestimulus baseline. Only correct trials were used in the averaging process. The resulting waveforms were quantified by mean-amplitude measures in two time windows, 200-400 and 400-600 msec. Results from a previous study (Münte, Say, et al., 1999) corroborated by visual inspection of the priming effects in the present experiment revealed a maximum at the central and parieto-occipital sites. Therefore, mean amplitudes were measured at the central posterior parasagittal sites (C3/ 4, $\mathrm{CP} 1 / 2, \mathrm{P} 3 / 4, \mathrm{PO} 1 / 2, \mathrm{O} 1 / 2$ ) for each time window and subjected to a repeated measures ANOVA. ANOVAs were conducted separately for verbs and nonce verbs with "regularity" ("regular" vs. "irregular"), "priming" (related vs. unrelated), "electrode" (five levels), and "hemisphere" (left vs. right) as within-subject factors. Similar analyses were performed on the performance data (mean RTs and percentages of errors). All ERP waveforms displayed in the figures were digitally filtered using a low-pass filter with a 6-Hz half-power cutoff. However, mean amplitudes used in all the statistical analyses reported were computed with unfiltered waveforms. For all statistical effects involving two or more degrees of freedom in the numerator, the Huynh-Feldt epsilon was used and the exact $p$ value after correction is shown below. All tests involving Electrode $\times$ Condition interactions were corrected prior to analysis using the vector normalization procedure (McCarthy \& Wood, 1985).

\section{APPENDIX: STIMULI USED IN THE PRESENT STUDY: PRESENT/INFINITIVE FORMS}

\section{Verbs With Alternated Stems (“Irregular”)}

abuñolar/abuñuelo; acertar/acierto; acostar/acuesto; adquirir/adquiero; advertir/advierto; amoblar/amueblo; apacentar/apaciento; apostar/apuesto; arrendar/arriendo; ascender/asciendo; avergonzar/avergüenzo; calentar/caliento; ceñir/ciño; cerrar/cierro; cocer/cuezo; colar/cuelo; colgar/cuelgo; concebir/concibo; concordar/concuerdo; confesar/confieso; costar/cuesto; defender/defiendo; degollar/degüello; derretir/derrito; desalentar/desaliento; desapretar/desaprieto; desdentar/desdiento; desenterrar/desentierro; deshelar/deshielo; desherrar/deshierro; desoldar/desueldo; desollar/ desuello; desosar/deshueso; despertar/despierto; despezar/despiezo; discernir/discierno; dormir/duermo; elegir/ elijo; embestir/embisto; emparentar/empariento; empezar/empiezo; emporcar/empuerco; encender/enciendo; engrosar/engrueso; enhestar/enhiesto; ensangrentar/ensangriento; entender/entiendo; erguir/yergo; errar/yerro; forzar/fuerzo; fregar/friego; gemir/gimo; hendir/ hiendo; herir/hiero; hervir/hiervo; holgar/huelgo; maldecir/maldigo; medir/mido; mentir/miento; merendar/meriendo; morder/muerdo; morir/muero; mostrar/muestro; mover/muevo; negar/niego; oler/huelo; perder/pierdo; perseguir/persigo; poder/puedo; probar/pruebo; quebrar/quiebro; recaer/recaigo; recomendar/recomiendo; recontar/recuento; referir/refiero; regar/riego; rendir/rindo; renovar/renuevo; repensar/repienso; repetir/repito; replegar/repliego; repoblar/repueblo; requerir/requiero; restregar/restriego; retronar/retrueno; reventar/reviento; rodar/ruedo; rogar/ruego; salpimentar/salpimiento; segar/siego; sembrar/siembro; sentir/siento; serrar/sierro; servir/sirvo; sofreír/sofrío; soltar/suelto; sonar/sueno; sonreír/sonrío; sugerir/sugiero; temblar/tiemblo; teñir/ tiño; tentar/tiento; torcer/tuerzo; tostar/tuesto; traer/ traigo; trocar/trueco; tropezar/tropiezo; verter/vierto; volcar/vuelco; volver/vuelvo.

\section{Verbs With Nonalternated Stems (“Regular”)}

abatir/abato; abrazar/abrazo; aclarar/aclaro; acudir/acudo; admirar/admiro; agitar/agito; aprender/aprendo; asumir/asumo; bautizar/bautizo; calcular/calculo; cocinar/ cocino; coincidir/coincido; cometer/cometo; comprender/comprendo; confirmar/confirmo; conformar/conformo; confundir/confundo; conservar/conservo; contestar/ contesto; copiar/copio; correr/corro; cosechar/cosecho; deber/debo; decidir/decido; declarar/declaro; decorar/ decoro; definir/defino; dejar/dejo; depender/dependo; derrumbar/derrumbo; descargar/descargo; desconfiar/ desconfío; describir/describo; desertar/deserto; designar/designo; desistir/desisto; desvivir/desvivo; dimitir/dimito; discutir/discuto; donar/dono; dudar/dudo; echar/ echo; emocionar/emociono; enjuagar/enjuago; escuchar/escucho; esperar/espero; exclamar/exclamo; existir/existo; frecuentar/frecuento; fundir/fundo; guardar/ guardo; ignorar/ignoro; imaginar/imagino; incomodar/ incomodo; inhibir/inhibo; insistir/insisto; instalar/instalo; lanzar/lanzo; lavar/lavo; levantar/levanto; limitar/limito; llamar/llamo; llevar/llevo; maltratar/maltrato; manejar/ manejo; meter/meto; nadar/nado; notar/noto; operar/ opero; opinar/opino; pegar/pego; percibir/percibo; permitir/permito; persistir/persisto; planchar/plancho; preguntar/pregunto; pretender/pretendo; procurar/ 
procuro; prometer/prometo; pulir/pulo; quitar/quito; rebuscar/rebusco; recubrir/recubro; rematar/remato; remitir/remito; remontar/remonto; repintar/repinto; responder/respondo; resumir/resumo; reunir/reuno; revelar/revelo; revender/revendo; rimar/rimo; romper/ rompo; roncar/ronco; rozar/rozo; sacudir/sacudo; someter/someto; sopesar/sopeso; soportar/soporto; sorprender/sorprendo; sospechar/sospecho; sufrir/sufro; suprimir/suprimo; temer/temo; tolerar/tolero; toser/toso; tullir/tullo; vaciar/vacio; vagar/vago.

\section{Nonce Verbs With Alternated Stems (“Irregular”)}

atuñolar/atuñuelo; apertar/apierto; esostar/esuesto; adguirir/adguiero; adnertir/adnierto; acoblar/acueblo; asacentar/asaciento; abostar/abuesto; arresdar/arriesdo; eslender/esliendo; evirgonzar/evirguenzo; palentar/paliento; cedir/cido; verrar/vierro; pocer/puezo; codar/cuedo; tolmar/tuelmo; cancepir/cancipo; conposdar/ conpuesdo; contenar/contieno; vostar/vuesto; desenter/desiento; tegomar/tegüemo; virretir/virrito; desolentar/desoliento; decapretar/decaprieto; despenbar/ despienbo; desanzerrar/desanzierro; desfelar/desfielo; deslerrar/deslierro; pecoldar/pecueldo; vetollar/vetuello; pesotar/peshueto; nesbertar/nesbierto; destezar/destiezo; daslernir/daslierno; dornir/duerno; blegir/blijo; esbestir/esbisto; ancarentar/ancariento; ompetar/ompieto; embortar/embuerto; incenter/inciento; ungrobar/ungruebo; enpestar/enpiesto; enpongrentar/enpongriento; anfender/anfiendo; esguir/yesgo; emar/yemo; fordar/ fuerdo; frevar/frievo; gebir/gibo; lendir/liendo; hetir/hieto; mervir/miervo; holdar/hueldo; nalmecir/nalmigo; xedir/xido; mensir/mienso; nemendar/nemiendo; mosder/ muesdo; mopir/muepo; moscrar/muescro; moser/mueso; nerar/niero; oger/uego; pelter/pielto; perteguir/pertigo; poser/pueso; bropar/bruepo; guebrar/guiebro; retaer/retaigo; recosempar/recosiempo; reconfar/recuenfo; rederir/rediero; fegar/fiego; rentir/rinto; revovar/revuevo; redensar/redienso; repefir/repifo; xeplecar/ xeplieco; revoblar/revueblo; requesir/requieso; restrevar/restrievo; refronar/refrueno; repentar/repiento; ronar/rueno; rofar/ruefo; salcipentar/salcipiento; tegar/ tiego; semprar/siempro; sescir/siesco; semmar/siemmo; serlir/sirlo; sogreír/sogrío; poltar/puelto; sodar/suedo; cosreír/cosrío; suserir/susiero; tesplar/tiesplo; señir/siño; lentar/liento; vorcer/vuerzo; sostar/suesto; craer/craigo; trofar/truefo; tralezar/traliezo; perter/pierto; voscar/vuesco; volner/vuelno.

\section{Nonce Verbs With Nonalternated Stems ("Regular")}

asatir/asato; arrabar/arrabo; aclanar/aclano; atudir/atudo; adsirar/adsiro; anitar/anito; aprenter/aprento; asupir/asupo; nausizar/nausizo; cascular/casculo; cobinar/cobino; cointidir/cointido; cofeter/cofeto; combrender/combrendo; conpirmar/conpirmo; cosfornar/cosforno; vonfuntir/ vonfunto; conxertar/conxerto; convestar/convesto; coniar/conio; coller/collo; copechar/copecho; deser/deso; becidir/becido; meclarar/meclaro; zecorar/zecoro; detinir/detino; denar/deno; depesder/depesdo; desnumbar/ desnumbo; bescargar/bescargo; desconviar/desconvío; dancribir/dancribo; tesertar/teserto; desitnar/desitno; denistir/denisto; descivir/descivo; dicitir/dicito; discunir/ discuno; bomar/bomo; dufar/dufo; ensar/enso; etocionar/etociono; enguagar/enguago; esmuchar/esmucho; esterar/estero; enclafar/enclafo; ezistir/ezisto; frenuensar/frenuenso; funvir/funvo; guarfar/guarfo; isnorar/isnoro; isaginar/isagino; incotodar/incotodo; indibir/ indibo; ingistir/ingisto; insvalar/insvalo; larzar/larzo; satar/sato; mesantar/mesanto; timitar/timito; dramar/ dramo; lletar/lleto; malbratar/malbrato; matejar/matejo; meser/meso; nasar/naso; novar/novo; amerar/amero; otinar/otino; pebar/pebo; pertibir/pertibo; mersitir/mersito; penfistir/penfisto; blanchar/blancho; preluntar/ prelunto; preteler/pretelo; pronurar/pronuro; brometer/brometo; puvir/puvo; tritar/trito; renuscar/renusco; recufrir/recufro; retatar/retato; renisir/reniso; refontar/ refonto; repistar/repisto; resbonder/resbondo; recumir/ recumo; reumir/reumo; refelar/refelo; redender/redendo; ridar/rido; ronter/ronto; rorcar/rorco; bozar/bozo; samudir/samudo; vometer/vometo; sofesar/sofeso; sonorbar/sonorbo; sorbrender/sorbrendo; saspechar/saspecho; pufrir/pufro; sutrimir/sutrimo; teber/tebo; tolecar/toleco; zoser/zoso; tunnir/tunno; taciar/tacio; vafar/vafo.

\section{Acknowledgments}

This work was supported by a NATO Collaborative Research grant (Project No. 970636) jointly awarded to A.R.F., H.C., and T.F.M. and a DFG grant MU 1311/7-1. A.R.F. was supported by a Postdoctoral Fellowship from the Spanish Government. We are grateful to Tessa Say, Fraibet Aveledo, Iggy Roca, Helga Weyerts, and Ingrid Sonnenstuhl for useful comments on an earlier version of this article and to Mayella Almazan for help in stimulus construction.

Reprint requests should be sent to Dr. Thomas F. Münte, Department of Neuropsychology, Otto von Guericke University, Universitätsplatz 2, Gebäude 24, 39106 Magdeburg, Germany, or via e-mail: thomas.muente@medizin.uni-magdeburg.de.

\section{Notes}

1. When the priming effect were assessed independently for regular and irregular verbs using a paired $t$ test, both effects were statistically reliable [regular verbs, $t(13)=-5.17, p<$ $.001,27$-msec difference; irregular verbs, $t(13)=-2.37, p<$ .034, 22-msec difference].

2. Note that in many direct (recognition task) and indirect (repetition) tasks a second, later effect, usually attributed to a modulation of the LPC is found. In his classic study, Rugg (1990) studied within-list (lag 6) and across-list (lag 15 min) repetition effect for low- and high-frequency words. He found a modulation of the ERP in the N400 region for both, high- and low-frequency words in the within-list condition. In addition, the post-500-msec latency region of the ERPs exhibited a substantial repetition effect for low-frequency words, but did 
not differentiate unrepeated and repeated high-frequency words. In the across-list condition, ERPs evoked by "old" and "new" high-frequency words did not differ in any latency region, while those evoked by old and new low-frequency words differed only after $500 \mathrm{msec}$. Thus, the current morphological priming effects resemble Rugg's repetition priming findings in high-frequency words.

3. Note that this dissociation pattern neither proves that unmarked and marked stems are processed by different brain systems in the present task nor do we claim that this is the case. Rather, the data suggest that the difference in N400 modulation results because of the fact that marked stems have their own mental representation.

\section{REFERENCES}

Alameda, J. R., \& Cuetos, F. (1995). Diccionario de frecuencias de las unidades linguisticas del castellano. Oviedo: Servicio de Publicaciones Universidad de Oviedo.

Bentin, S., \& Peled, B. S. (1990). The contribution of taskrelated factors to ERP repetition effects at short and long lags. Memory and Cognition, 33, 132-147.

Brown, C. M., \& Hagoort, P. (1993). The processing nature of the N400: Evidence from masked priming. Journal of Cognitive Neuroscience, 5, 34-44.

Bybee, J. L., \& Pardo, E. (1981). On lexical and morphological conditioning of alternations: A nonce-probe experiment with Spanish verbs. Linguistics, 19, 937-968.

Cappa, S., \& Ullman, M. (1998). The processing of Italian regular and irregular verbal morphology in patients with probable Alzheimer's disease. Journal of Cognitive Neuroscience, SS, 53.

Chwilla, D. (1996). Electrophysiology of word processing: The lexical processing nature of the $N 400$ priming effect. Doctoral dissertation, Nijmegen University.

Clahsen, H. (1999). Lexical entries and rules of language: A multidisciplinary study of German inflection. Behavioral Brain Sciences, 22, 991-1013.

Doyle, M. C., Rugg, M. D., \& Wells, T. (1996). A comparison of the electrophysiological effects of formal and repetition priming. Psychophysiology, 33, 132-147.

Elman, J., Bates, E., Johnson, M., Karmiloff-Smith, A. Parisi, D., \& Plunkett, K. (1996). Rethinking innateness. Cambridge: MIT Press.

Fowler, C., Napps, S., \& Feldman, L. B. (1985). Relations among regular and irregular morphologically related words in the lexicon as revealed by repetition priming. Memory and Cognition, 13, 241-255.

Gross, M., Say, T., Kleingers, M., Clahsen, H., \& Münte, T. F. (1998). Human brain potentials to violations in morphologically complex Italian words. Neuroscience Letters, 241, 83-86.

Harris, J. W. (1969). Spanish phonology. Cambridge: MIT Press.

Holcomb, P. J. (1993). Semantic priming and stimulus degradation: Implications for the role of the N400 in language processing. Psychophysiology, 30, 47-61.

Indefrey, P., Brown, C., Hagoort, P., Herzog, H., Sach, M., \& Seitz, R. J. (1997). A PET study of cerebral activation patterns induced by verb inflection. Neuroimage, 5, S548.

Jaeger, J., Lockwood, A., Kemmerer, D., Van Valin, R., Murphy, B., \& Khalak, H. (1996). A positron emission tomographic study of regular and irregular verb morphology in English. Language, 72, 451-497.

Joanisse, M. F., \& Seidenberg, M. S. (1999). Impairments in verb morphology after brain injury: A connectionist model. Proceedings of the National Academy of Science, U.S.A., 96, 7592-7597.
Karayanidis, F., Andrews, S., Ward, P. B., \& McConaghy, N. (1991). Effects of inter-item lag on word repetition: An eventrelated potential study. Psychophysiology, 28, 307-318.

Kempley, S., \& Morton, J. (1982). The effects of priming with regularly and irregularly related words in auditory word recognition. British Journal of Psychology, 73, 441-454.

Kounious, J., \& Holcomb, P. J. (1992). Structure and process in semantic memory: Evidence from event-related brain potentials and reaction times. Journal of Experimental Psychology, 121, 460-480.

Kutas, M., \& Federmeier, K. D. (2000). Electrophysiology reveals semantic memory use in language comprehension. Trends in Cognitive Science, 4, 463-470.

Luck, S. J., Vogel, E. K., \& Shapiro, K. L. (1996). Word meanings can be accessed but not reported during the attentional blink. Nature, 383, 616-618.

Marslen-Wilson, W., Hare, M., \& Older, L. (1993). Inflectional morphology and phonological regularity in the English mental lexicon. Proceedings of the Fifteenth Annual Conference of the Cognitive Science Society (pp. 1-6). Hillsdale, NJ: Erlbaum.

Marslen-Wilson, W. D., \& Tyler, L. (1997). Dissociating types of mental computation. Nature, 387, 592-594.

Marslen-Wilson, W. D., \& Tyler, L. K. (1998). Rules, representations, and the English past tense. Trends in Cognitive Sciences, 2, 428-435.

McCarthy, G., \& Wood, C. (1985). Scalp distributions of event-related potentials: An ambiguity associated with analysis of variance models. Electroencephalography and Clinical Neurophysiology, 62, 203-208.

Moliner, M. (1998). Diccionario de uso del español (2nd ed.). Madrid: Gredos.

Münte, T. F., Rodriguez-Fornells, A., \& Kutas, M. (1999). One, two, or many mechanisms? The brain's processing of complex words. Behavioral and Brain Sciences, 22, 1021.

Münte, T. F., Say, T., Clahsen, H., Schiltz, K., \& Kutas, M. (1999). Decomposition of morphologically complex words in English: Evidence from event-related brain potentials. Cognitive Brain Research, 7, 241-253.

Nagy, M., \& Rugg, M. D. (1989). Modulation of event-related potentials by word repetition: The effects of inter-item lag. Psychophysiology, 26, 431-436.

Napps, S. (1998). Morphemic relationships in the lexicon: Are they distinct from semantic and formal relationships? Memory and Cognition, 17, 729-739.

Orsolini, M., \& Marslen-Wilson, W. D. (1997). Universals in morphological representation: Evidence from Italian. Language and Cognitive Processes, 12, 1-47.

Penke, M., Weyerts, H., Gross, M., Zander, E., Münte, T. F., \& Clahsen, H. (1997). How the brain processes complex words: An event-related potential study of German verb inflections. Cognitive Brain Research, 6, 37-52.

Pinker, S. (1997). Words and rules in the human brain. Nature, 387, 547-548.

Real Academia Española. (1998). Esbozo de una nueva gramática de la lengua espanola (17th ed.). Madrid: Espasa Calpe.

Rodriguez-Fornells, A., Clahsen, H., Lleó, C., Zaake, W., \& Münte, T. F. (2001). Event-related brain responses to morphological violations in Catalan. Cognitive Brain Research, 11, 47-58.

Rueckl, J. G., Mikolinskis, M., Raveh, M., Miner, C. S., \& Mars, F. (1997). Morphological priming, fragment completion, and connectionist networks. Journal of Memory and Language, 36, 382-405.

Rugg, M. D. (1990). Event-related brain potentials dissociate repetition effects of high- and low-frequency words. Memory and Cognition, 18, 367-379. 
Rugg, M. D. (1995). ERP studies of memory. In M. D. Rugg, \& M. G. H. Coles (Eds.), Electrophysiology of mind (pp. 132-170). New York: Oxford University Press.

Rugg, M. D., \& Nagy, M. E. (1987). Lexical contribution to nonword-repetition effects: Evidence from event-related potentials. Memory and Cognition, 15, 473-481.

Say, T., \& Clahsen, H. (2002). Words, rules and stems in the Italian mental lexicon. In S. Nooteboom, F. Weerman, \& F. Wijnen (Eds.), Storage and computation in the language faculty (pp. 75-108). Dordrecht: Kluwer.

Seidenberg, M. S., \& Hoeffner, J. (1998). Evaluating behavioral and neuroimaging evidence about past tense processing. Language, 74, 104-122.

Sonnenstuhl, I., Eisenbeiss, S., \& Clahsen, H. (1999). Morphological priming in the German mental lexicon. Cognition, 72, 203-236.

Stanners, R., Neiser, J., Hernon, W., \& Hall, R. (1979). Memory representation for morphologically related words. Journal of Verbal Learning and Verbal Behavior, 18, 399-412.

Ullman, M., Corkin, S., Coppola, M., Hickok, G., Growdon, J. H., Koroshetz, W. J., \& Pinker, S. (1997). A neural dissociation within language: Evidence that the mental dictionary is part of declarative memory, and that grammatical rules are processed by the procedural system. Journal of Cognitive Neuroscience, 9, 266-276.

Van Petten, C., Kutas, M., Kluender, R., Mitchiner, M., \& McIsaac, H. K. (1991). Fractionating the word repetition effect with event-related potentials. Journal of Cognitive Neuroscience, 3, 131-150.

Vogel, E. K., Luck, S. J., \& Shapiro, K. L. (1998). Electrophysiological evidence for a postperceptual locus of suppression during the attentional blink. Journal of Experimental Psychology, Human Perception and Performance, 24, 1656-1674.

Weyerts, H., Münte, T. F., Smid, H. G., \& Heinze, H. J. (1996). Mental representations of morphologically complex words: An event-related potential study with adult humans. Neuroscience Letters, 206, 125-128.

Weyerts, H., Penke, M., Dohrn, U., Clahsen, H., \& Münte, T. F. (1997). Brain potentials indicate differences between regular and irregular German plurals. NeuroReport, 8, 957-962.

Wunderlich, D. (1996). Minimalist morphology: The role of paradigms. Yearbook of Morphology, 1995, 93-114. 